\title{
Inter-nesting distribution of flatback turtles Natator depressus and industrial development in Western Australia
}

\author{
Paul A. Whittock ${ }^{1,2, *}$, Kellie L. Pendoley ${ }^{1}$, Mark Hamann ${ }^{2}$ \\ ${ }^{1}$ Pendoley Environmental Pty Ltd, 12a Pitt Way, Booragoon, WA 6154, Australia \\ ${ }^{2}$ School of Earth and Environmental Sciences, James Cook University, Townsville, QLD 4811, Australia
}

\begin{abstract}
Offshore interactions of inter-nesting flatback turtles Natator depressus with resource industry activities are potentially frequent, yet the associated impact is largely unquantified. Consequently, there is a need to understand the degree of interaction and to provide data that can assist with effective conservation and management. We used satellite tracking to highlight the potential interaction of inter-nesting flatback turtles $(n=56)$ from 4 rookeries in Western Australia with regional resource industry activities. Flatback turtles demonstrated varying inter-nesting movements, with displacement distances ranging from 3.4 to $62.1 \mathrm{~km}$. Some turtles at all 4 rookeries remained $<10 \mathrm{~km}$ from the nesting beach. Core home range areas for inter-nesting flatback turtles ranged from 1.4 to $601.1 \mathrm{~km}^{2}$. The proportion of core home range areas for Thevenard and Barrow Island turtles that overlapped offshore petroleum title areas was 85.7 and $88.6 \%$, respectively. The proportion of median daily positions that overlapped petroleum title areas was also high, $80.8 \%$ (Thevenard) and $87.3 \%$ (Barrow). There was no overlap of home range areas and median daily positions with petroleum title areas for Mundabullangana and Port Hedland turtles, although some inter-nesting movements of Port Hedland turtles were in close proximity to a proposed port expansion. The wide-ranging inter-nesting movement patterns highlight a need for the Australian Government and industry to expand the scope of Environmental Impact Assessments, ensuring adequate protection is provided to inter-nesting flatback turtles. The similar nearshore inter-nesting movement pattern recorded by some flatback turtles at each rookery provides an opportunity to establish boundaries for small-scale spatial and temporal protection measures.
\end{abstract}

KEY WORDS: Flatback $\cdot$ Inter-nesting $\cdot$ Satellite tracking $\cdot$ Australia $\cdot$ Industry $\cdot$ Environmental Impact Assessment · EIA

\section{INTRODUCTION}

Interaction between industrial development activities and protected fauna species is of worldwide concern (Gill 2005, Halpern et al. 2008). Interactions can negatively affect distribution (Carstensen et al. 2006, Harewood \& Horrocks 2008), behaviour (Leung Ng \& Leung 2003, Thompson et al. 2010) and health (Madsen et al. 2006, Stewart et al. 2007) of terrestrial and marine species during different phases of their life

${ }^{*}$ Corresponding author: paul.whittock@penv.com.au cycle. Expansion of traditional industrial development activities (e.g. mineral extraction processes) and, more recently, activities related to renewable energy developments (e.g. wind farms, tidal barriers), into 'untouched' remote coastal and offshore regions, provides further opportunity for interaction between breeding and migration life phases of marine species (Gill 2005). While the potential impact of interactions has been documented for some migrating marine species (Bailey et al. 2010, Maxwell et al. 2013), for

(C) The authors 2014. Open Access under Creative Commons by Attribution Licence. Use, distribution and reproduction are unrestricted. Authors and original publication must be credited. 
breeding and migratory marine turtles, the potential overlap with industrial activities remains of concern.

Marine turtles lay multiple clutches of eggs, spend several months in proximity to the nesting beach between successive clutches (Miller 1997, Hamann et al. 2002) and typically demonstrate strong site fidelity, laying each of their clutches on the same beach or island. As capital breeders, marine turtles are understood to show inactive behaviour during the inter-nesting period (the period between a successful clutch and the next nesting attempt) (Hays et al. 1999, Fossette et al. 2012), presumably to conserve energy for successive reproductive events (see Hays et al. 1999). However, little is known about the behaviour of females offshore during this period compared to during nesting and post-nesting migration periods (Hamann et al. 2010). Research on female behaviour during the inter-nesting period is important, as offshore inter-nesting habitat adjacent to nesting beaches is typically afforded fewer protection measures than nesting beaches (see Dryden et al. 2008).

The movement of turtles during the inter-nesting period varies considerably between and within populations. Turtles from some populations remain in close proximity to the nesting beach (loggerhead turtles: e.g. Stoneburner 1982, Godley et al. 2003; green turtles: e.g. Hays et al. 1999, Craig et al. 2004, Troëng et al. 2005, Fuller et al. 2008; hawksbill turtles: e.g. Troëng et al. 2005a, Whiting et al. 2006; Kemp's ridley turtles: e.g. Seney \& Landry 2008, Shaver \& Rubio 2008; olive ridley turtles: e.g. Maxwell et al. 2011), while turtles from other populations undertake long distance migrations (loggerhead: e.g. Blumenthal et al. 2006, Schofield et al. 2013; leatherback: e.g. Eckert 2006, Shillinger et al. 2010; olive ridley: e.g. Hamel et al. 2008). Similarly, the degree to which inter-nesting habitats are anthropogenically used and managed also varies considerably (see Zbinden et al. 2007, Maxwell et al. 2011).

The flatback turtle Natator depressus offers a useful case study in this regard. Its nesting is endemic to the Australian continental shelf and is widespread and abundant in northern Australia (see Limpus 2007). Nesting sites and patterns of site fidelity are well known (Limpus 2007), with 4 genetic units/ stocks currently recognised; Western Australia, Northern Territory, Gulf of Carpentaria and eastern Australia (Dutton et al. 2002). The breeding (nesting) range of the flatback turtles in Western Australia extends easterly from Cape Range to Cape Domett, with the most significant concentration of rookeries found in the Pilbara region (see Fig. 1) (Limpus 2007). The Pilbara region is rich in hydro- carbon and mineral resources, making it an area of great economic importance for the State and Commonwealth governments (Human \& McDonald 2009). The same region also hosts a substantial and rapidly expanding industrial resource sector, with dredging, coastal development and infrastructure for mineral storage, processing and transport facilities, located on, or near to, several flatback rookeries (Limpus 2007). Fatal interactions of inter-nesting flatback turtles with resource sector activities can potentially occur (e.g. Dickerson et al. 1991, Lutcavage et al. 1995), yet the associated impact is understudied and unquantified (Limpus 2007), outside that presented in Environmental Impact Assessments (EIA). There is only one published account of offshore habitat use by flatback turtles in Western Australia (Waayers et al. 2011), with no consideration for offshore interaction with resource sector activities. Consequently, there is a clear need to understand the degree of interaction between anthropogenic development and flatback turtles and, ultimately, to provide data that can assist with effective management through EIAs and developmentorientated monitoring/management plans.

Inter-nesting habitats and interconnected migratory pathways host dense aggregations of adult marine turtles (Godley et al. 2008, Pendoley et al. 2014). The paucity of data on flatback turtle habitat use, abundance and distribution among habitats during key life stages, when considered together with the scale of marine and coastal development, inhibits effective conservation and management planning which would mitigate further potential threats of anthropogenic development. Our aim was thus to identify the abundance and distribution of inter-nesting turtles using satellite telemetry, to gain a better understanding of how flatback turtle inter-nesting movement patterns vary between rookeries. We also relate flatback turtle distribution and the location of core home range areas to resource sector developments and lease title areas so as to identify the extent to which they overlap and to support the development and implementation of improved and effective impact assessment and management practices.

\section{MATERIALS AND METHODS}

\section{Study sites}

We tracked female flatback turtles from 4 flatback rookeries within the same genetic management unit in the Pilbara region of Western Australia: Theve- 


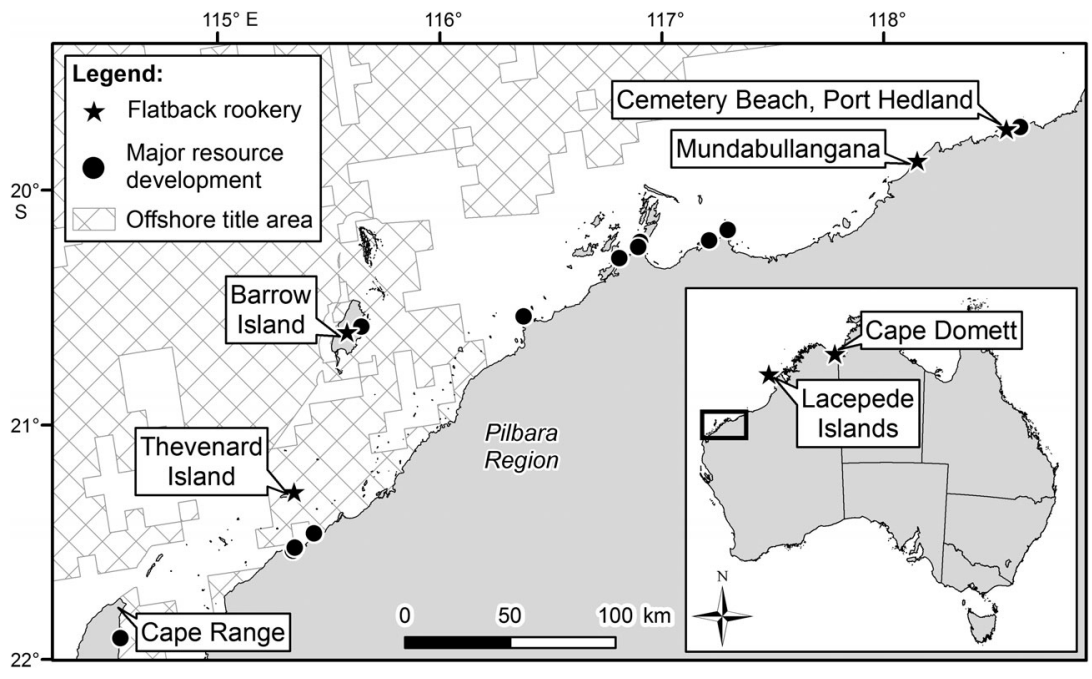

Fig. 1. Location of Thevenard Island, Barrow Island, Mundabullangana and Cemetery Beach, Port Hedland flatback turtle rookeries in relation to major resource developments and offshore petroleum title areas in Western Australia

nard Island (Thevenard), Barrow Island (Barrow), Mundabullangana (Munda) and Cemetery Beach, Port Hedland (Cemetery). The 4 rookeries are separated by a maximum distance of $\sim 350 \mathrm{~km}$ (Fig. 1).

Thevenard is situated $20 \mathrm{~km}$ off the mainland coast, and flatback nesting occurs on the island's south coast (Fig. 1). The beach ranges in width from 5 to $30 \mathrm{~m}$ (K. Pendoley unpubl. data). Thevenard Island is a production hub for 6 oil and gas fields located within a $17 \mathrm{~km}$ radius. It has an oil and gas processing and storage facility located on the eastern end of the island immediately adjacent to the flatback nesting beach. Barrow is situated $60 \mathrm{~km}$ off the mainland coast and has 6 flatback nesting beaches on the east coast. The beaches range from 500 to $1100 \mathrm{~m}$ in length and 10 to $15 \mathrm{~m}$ in width and are bounded by rocky headlands at each end (Pendoley 2005). A large-scale liquefied natural gas processing facility is currently under construction on the central east coast of the island and involves construction of substantial offshore infrastructure and vessel activity (Fig. 1). Munda is $60 \mathrm{~km}$ west of Port Hedland on the mainland coast and is isolated from coastal development. The main nesting site at Munda is Cowrie Beach, a $3.3 \mathrm{~km}$ long beach bounded by a mangrove creek to the north-east and a rocky headland to the southwest. Cemetery Beach is the main town beach for Port Hedland, which is home to the largest bulk minerals export port in the world and the site of a planned large port expansion project (Fig. 1). The beach is $1 \mathrm{~km}$ long and 10 to $15 \mathrm{~m}$ wide and has been substantially modified by the creation of a dredge spoil spit located to the west of the beach.

\section{Data collection}

Fifty-six adult female flatback turtles (curved carapace length range: 85 $99 \mathrm{~cm}$ ) were tracked between 2005/06 and 2010/11: Thevenard $(n=6)$, Barrow $(\mathrm{n}=33)$, Munda $(\mathrm{n}=2)$ and Cemetery $(n=15)$ (Table 1). To ensure inter-nesting data was gathered, transmitters were deployed on nesting turtles at the beginning of the nesting season. It was unknown if the selected turtles were nesting for the first time in the season at the time of attachment; therefore, data presented in this study may not represent the overall season's inter-nesting distribution for each tracked turtle.

We used 4 different models of transmitter over the course of this study, 2 models (KiwiSat101, $\mathrm{n}=9$ [Sirtrack] and MK-10, $\mathrm{n}=$ 6 [Wildlife Computers]) provided Argos only locations, and 2 models (Fastloc GPS-Argos transmitters, $\mathrm{n}=12$ [Sirtrack] and Satellite Relayed Data Loggers [SRDL], n = 29; [St Andrews Mammal Research Unit]) provided Fastloc GPS locations.

The standard method of attaching transmitters to hard-shelled turtles using epoxy resin is unsuitable for flatback turtles as they have a carapace covered by a soft and easily abraded skin (Sperling \& Guinea 2004). Transmitters were attached using a harness as outlined in the protocol described by Sperling \& Guinea (2004) for eastern Australian flatback turtles. Selected turtles were allowed to complete nesting prior to transmitter attachment.

Each transmitter was programmed to transmit data when at the surface, as indicated by a saltwater switch present on each transmitter. Transmitted data from both types of Argos tags (KiwiSat101 and MK-10) were collected using the Argos satellite system (CLS 2011) and downloaded and managed using the Satellite Tracking and Analysis Tool (STAT; Coyne \& Godley 2005). The Argos satellite system calculates the position of a transmitter by doppler shift of the transmission frequency as the satellite passes overhead, and the accuracy of the 'fix' (location class) is determined by the number of uplinks received by the satellite in a single overpass. The standard Argos unit accuracy is categorised by location classes (LC): LC 3, LC 2, LC 1 or LC 0 locations, which are classified as within 150, $>150$ to $350,>350$ to 1000 or $>1000 \mathrm{~m}$, respectively. Locations classified as Classes A and B indicate 
Table 1. Summary of transmitter deployment (2005/06 to 2010/11) at Thevenard Island (THV), Barrow Island (BWI), Mundabullangana (MDA) and Cemetery Beach, Port Hedland (CM), Western Australia. Dates are given as dd/mm/yr. CCL: curved carapace length; KDE: kernel density estimate; $50 \%$ UD: $50 \%$ utilisation distribution

\begin{tabular}{|c|c|c|c|c|c|c|c|c|c|c|}
\hline Year & $\begin{array}{c}\text { Turtle } \\
\text { no. }\end{array}$ & $\begin{array}{l}\mathrm{CCL} \\
(\mathrm{cm})\end{array}$ & $\begin{array}{l}\text { Attachment } \\
\text { location }\end{array}$ & Tag type & $\begin{array}{l}\text { Attachment } \\
\text { date }\end{array}$ & $\begin{array}{c}\text { End of } \\
\text { inter-nesting }\end{array}$ & $\begin{array}{l}\text { Tracked } \\
\text { days (n) }\end{array}$ & $\begin{array}{l}\text { Inter-nesting } \\
\text { periods }(\mathrm{n})\end{array}$ & $\begin{array}{c}\mathrm{KDE}(50 \% \\
\mathrm{UD}) \text { area }\left(\mathrm{km}^{2}\right)\end{array}$ & $\begin{array}{l}\text { Proportion of KDE (50\% } \\
\text { UD) in title area (\%) }\end{array}$ \\
\hline $2005 / 06$ & 1 & 90 & BWI & Argos & $29 / 11 / 2005$ & $28 / 12 / 2005$ & 29 & 2 & - & - \\
\hline $2005 / 06$ & 2 & 94 & BWI & Argos & $06 / 12 / 2005$ & $06 / 01 / 2006$ & 31 & 2 & - & - \\
\hline $2005 / 06$ & 3 & 90 & BWI & Argos & $02 / 12 / 2005$ & $01 / 01 / 2006$ & 30 & 2 & - & - \\
\hline $2005 / 06$ & 4 & 88 & BWI & Argos & $01 / 12 / 2005$ & $30 / 12 / 2005$ & 29 & 2 & - & - \\
\hline $2006 / 07$ & 5 & 85 & BWI & Argos & $18 / 12 / 2006$ & $14 / 01 / 2007$ & 27 & 2 & - & - \\
\hline $2006 / 07$ & 6 & 86 & BWI & Argos & $09 / 01 / 2007$ & $19 / 01 / 2007$ & 10 & 1 & - & - \\
\hline $2006 / 07$ & 7 & 88 & BWI & GPS & $15 / 12 / 2006$ & $03 / 01 / 2007$ & 19 & 1 & 158.5 & 82.5 \\
\hline $2006 / 07$ & 8 & 87 & BWI & GPS & $18 / 01 / 2007$ & $13 / 02 / 2007$ & 26 & 2 & 182.5 & 81.9 \\
\hline $2007 / 08$ & 9 & 91 & BWI & Argos & $15 / 12 / 2007$ & $30 / 12 / 2007$ & 15 & 1 & - & - \\
\hline $2007 / 08$ & 10 & 89 & BWI & GPS & $16 / 12 / 2007$ & $05 / 01 / 2008$ & 20 & 1 & 6.3 & 100.0 \\
\hline $2007 / 08$ & 11 & 92 & BWI & GPS & $13 / 12 / 2007$ & $11 / 01 / 2008$ & 29 & 2 & 11.8 & 100.0 \\
\hline 2008/09 & 12 & 86 & BWI & GPS & $18 / 12 / 2008$ & 03/01/2009 & 16 & 1 & 141.7 & 100.0 \\
\hline 2008/09 & 13 & 90 & BWI & GPS & $18 / 12 / 2008$ & $31 / 12 / 2008$ & 13 & 1 & 5.3 & 100.0 \\
\hline 2008/09 & 14 & 90 & BWI & GPS & $17 / 12 / 2008$ & $24 / 01 / 2009$ & 38 & 3 & 244.4 & 47.1 \\
\hline 2008/09 & 15 & 90 & BWI & GPS & $17 / 12 / 2008$ & $13 / 01 / 2009$ & 27 & 2 & 497.0 & 92.9 \\
\hline $2009 / 10$ & 16 & 90 & BWI & GPS & $29 / 11 / 2009$ & $13 / 12 / 2009$ & 14 & 1 & 39.6 & 100.0 \\
\hline $2009 / 10$ & 17 & 88 & BWI & GPS & $02 / 12 / 2009$ & $15 / 12 / 2009$ & 13 & 1 & 490.7 & 70.9 \\
\hline $2009 / 10$ & 18 & 91 & BWI & GPS & $01 / 12 / 2009$ & $11 / 01 / 2010$ & 41 & 3 & 7.5 & 100.0 \\
\hline $2009 / 10$ & 19 & 89 & BWI & GPS & $03 / 12 / 2009$ & $09 / 01 / 2010$ & 37 & 3 & 90.2 & 88.2 \\
\hline $2009 / 10$ & 20 & 91 & BWI & GPS & $27 / 11 / 2009$ & $08 / 01 / 2010$ & 42 & 3 & 28.9 & 100.0 \\
\hline $2009 / 10$ & 21 & 96 & BWI & GPS & $28 / 11 / 2009$ & $28 / 12 / 2009$ & 30 & 2 & 318.3 & 96.8 \\
\hline $2009 / 10$ & 22 & 90 & BWI & GPS & $29 / 11 / 2009$ & 09/01/2010 & 41 & 3 & 97.4 & 100.0 \\
\hline $2009 / 10$ & 23 & 87 & BWI & GPS & $28 / 11 / 2009$ & $07 / 01 / 2010$ & 40 & 3 & 1.4 & 100.0 \\
\hline $2009 / 10$ & 24 & 91 & BWI & GPS & $02 / 01 / 2010$ & $19 / 01 / 2010$ & 17 & 1 & 601.1 & 74.4 \\
\hline $2009 / 10$ & 25 & 90 & BWI & GPS & 03/12/2009 & $14 / 01 / 2010$ & 42 & 3 & 3.1 & 100.0 \\
\hline $2009 / 10$ & 26 & 93 & BWI & GPS & $28 / 11 / 2009$ & $26 / 12 / 2009$ & 28 & 2 & 3.3 & 100.0 \\
\hline $2009 / 10$ & 27 & 96 & BWI & GPS & $01 / 12 / 2009$ & $11 / 01 / 2010$ & 41 & 3 & 20.3 & 100.0 \\
\hline $2009 / 10$ & 28 & 90 & BWI & GPS & $29 / 11 / 2009$ & $10 / 01 / 2010$ & 42 & 3 & 18.5 & 100.0 \\
\hline $2009 / 10$ & 29 & 88 & BWI & GPS & $01 / 12 / 2009$ & $29 / 12 / 2009$ & 28 & 2 & 176.7 & 27.6 \\
\hline $2009 / 10$ & 30 & 88 & BWI & GPS & $27 / 11 / 2009$ & $20 / 01 / 2010$ & 54 & 4 & 49.0 & 100.0 \\
\hline $2009 / 10$ & 31 & 87 & BWI & GPS & $29 / 11 / 2009$ & $14 / 12 / 2009$ & 15 & 1 & 269.8 & 46.6 \\
\hline $2009 / 10$ & 32 & 91 & BWI & GPS & $30 / 11 / 2009$ & $08 / 01 / 2010$ & 39 & 3 & 209.7 & 93.7 \\
\hline $2009 / 10$ & 33 & 88 & BWI & GPS & $01 / 12 / 2009$ & $20 / 01 / 2010$ & 50 & 4 & 47.8 & 100.0 \\
\hline $2005 / 06$ & 34 & 85 & MDA & Argos & $09 / 12 / 2005$ & $20 / 12 / 2005$ & 11 & 1 & - & - \\
\hline $2005 / 06$ & 35 & 90 & MDA & Argos & $10 / 12 / 2005$ & $01 / 01 / 2006$ & 22 & 2 & - & - \\
\hline $2008 / 09$ & 36 & 87 & $\mathrm{CM}$ & GPS & $08 / 12 / 2008$ & $04 / 01 / 2009$ & 27 & 2 & 64.5 & 0.0 \\
\hline 2008/09 & 37 & 85 & $\mathrm{CM}$ & GPS & $07 / 12 / 2008$ & $25 / 12 / 2008$ & 18 & 1 & 49.1 & 0.0 \\
\hline 2008/09 & 38 & 89 & $\mathrm{CM}$ & GPS & $06 / 12 / 2008$ & $30 / 12 / 2008$ & 24 & 2 & 166.9 & 0.0 \\
\hline $2008 / 09$ & 39 & 89 & $\mathrm{CM}$ & GPS & $06 / 12 / 2008$ & $19 / 12 / 2008$ & 13 & 1 & 132.6 & 0.0 \\
\hline $2009 / 10$ & 40 & 92 & $\mathrm{CM}$ & Argos & $12 / 12 / 2009$ & $15 / 01 / 2010$ & 34 & 3 & - & - \\
\hline $2009 / 10$ & 41 & 85 & $\mathrm{CM}$ & Argos & $09 / 12 / 2009$ & $02 / 01 / 2010$ & 24 & 2 & - & - \\
\hline $2009 / 10$ & 42 & 86 & $\mathrm{CM}$ & Argos & $12 / 12 / 2009$ & $22 / 12 / 2009$ & 10 & 1 & - & - \\
\hline $2009 / 10$ & 43 & 87 & $\mathrm{CM}$ & Argos & $10 / 12 / 2009$ & $22 / 12 / 2009$ & 12 & 1 & - & - \\
\hline $2009 / 10$ & 44 & 86 & $\mathrm{CM}$ & Argos & $12 / 12 / 2009$ & $05 / 01 / 2010$ & 24 & 2 & - & - \\
\hline $2009 / 10$ & 45 & 94 & $\mathrm{CM}$ & Argos & $11 / 12 / 2009$ & $24 / 12 / 2009$ & 13 & 1 & - & - \\
\hline 2010/11 & 46 & 88 & $\mathrm{CM}$ & GPS & $30 / 11 / 2010$ & $27 / 12 / 2010$ & 27 & 2 & 5.5 & 0.0 \\
\hline $2010 / 11$ & 47 & 91 & $\mathrm{CM}$ & GPS & $27 / 11 / 2010$ & $08 / 12 / 2010$ & 11 & 1 & 21.9 & 0.0 \\
\hline $2010 / 11$ & 48 & 90 & $\mathrm{CM}$ & GPS & $30 / 11 / 2010$ & $21 / 12 / 2010$ & 21 & 2 & 89.7 & 0.0 \\
\hline 2010/11 & 49 & 90 & $\mathrm{CM}$ & GPS & $01 / 12 / 2010$ & $06 / 01 / 2011$ & 36 & 3 & 146.1 & 0.0 \\
\hline $2010 / 11$ & 50 & 88 & $\mathrm{CM}$ & GPS & $26 / 11 / 2010$ & $30 / 12 / 2010$ & 34 & 3 & 4.6 & 0.0 \\
\hline $2010 / 11$ & 51 & 99 & THV & GPS & $14 / 12 / 2010$ & $18 / 01 / 2011$ & 35 & 3 & 138.5 & 87.5 \\
\hline 2010/11 & 52 & 92 & THV & GPS & $12 / 12 / 2010$ & $05 / 01 / 2011$ & 24 & 2 & 256.7 & 88.2 \\
\hline $2010 / 11$ & 53 & 89 & THV & GPS & $12 / 12 / 2010$ & $11 / 01 / 2011$ & 30 & 3 & 337.1 & 86.1 \\
\hline $2010 / 11$ & 54 & 98 & THV & GPS & $11 / 12 / 2010$ & $05 / 01 / 2011$ & 25 & 2 & 137.2 & 87.2 \\
\hline 2010/11 & 55 & 92 & THV & GPS & $11 / 12 / 2010$ & $27 / 12 / 2010$ & 16 & 1 & 191.3 & 75.2 \\
\hline 2010/11 & 56 & 89 & THV & GPS & $17 / 12 / 2010$ & $29 / 12 / 2010$ & 12 & 1 & 89.0 & 89.9 \\
\hline
\end{tabular}

fixes of poor accuracy (Hays et al. 2001) and only Argos locations LC 3, 2, 1 and 0 were used for analysis. To exclude implausible locations, the Argos dataset was filtered using the following criteria: (1) a minimum speed of travel was calculated between successive locations, and only those indi- cating travel speeds of $<5 \mathrm{~km} \mathrm{~h}^{-1}$ from the previous location were included (Hays et al. 2004, Shimada et al. 2012), and (2) successive fixes with turning angles $>25^{\circ}$ were also removed because acute turning angles are often indicative of erroneous 'offtrack' locations (Hawkes et al. 2007). 
The SRDL and Fastloc GPS-Argos tags incorporated both a Fastloc GPS receiver and an Argos Platform Terminal Transmitter (PTT). The Fastloc receiver captures GPS constellation data over a very short time period (within $100 \mathrm{~ms}$ ) allowing GPS data to be yielded from very brief surface intervals (Hazel 2009). This rapid acquisition method removed a number of transmission difficulties associated with recording GPS data from diving marine animals (Hays 2008). The GPS constellation data was saved onboard the tag and subsequently transmitted via the Argos satellite network. The accuracy of Fastloc GPS location estimates varies and locations generated using a higher number of satellites are known to be more accurate (8 satellites: $26 \pm 19.2 \mathrm{~m}$; 4 satellites: $172 \pm$ 372.5 m; Hazel 2009, Witt et al. 2010, Shimada et al. 2012). Therefore, we excluded Fastloc GPS positions generated from $<5$ satellites.

\section{Determination of inter-nesting periods}

We identified subsequent successful nesting events following transmitter deployment for each turtle to enable determination of individual inter-nesting periods. Exact dates and times of re-nesting events were identified for those turtles equipped with SRDL tags that transmitted 'haul-out' events, with the start of a haul-out event triggered once the tag was continuously dry for $>6 \mathrm{~min}$, and ending once the tag was continuously wet for $>40$ s. Successful nesting was defined by a haul-out event of $>40 \mathrm{~min}$, recorded on or near land $(<200 \mathrm{~m})$, with no subsequent haulout event recorded for the following $10 \mathrm{~d}$. For all other tag types, re-nesting events were inferred based on (1) directed nearshore movement, and (2) the position data, indicating that the turtle was not on, or adjacent to, the beach for the following $10 \mathrm{~d}$. A period of $10 \mathrm{~d}$ was selected, as $9 \mathrm{~d}$ is regarded as the physiological limit for the development of a new clutch of eggs (Miller 1985, Hamann et al. 2003). The nearshore bathymetry at all 4 study sites is consistently shallow and it was not suitable to use a sudden change in depth use as an indication of a nesting event, as used in other studies (Schofield et al. 2007). On occasion, turtles were also observed on the beach by staff, confirming the exact time and date of the occurrence of a nesting event. These direct observations were used to validate the process of using tracking data to infer re-nesting events.

The absolute end of inter-nesting was indicated by the commencement of post-nesting migration, which was deemed to have begun once movement away from the nesting beach was directional and protracted (Zbinden et al. 2008).

\section{Data analysis}

To avoid pseudo-replication when analysing our data, we used filtered location data (both Argos and Fastloc) to calculate a median daily position for each turtle (Schofield et al. 2010). Median daily positions were used to determine total distance travelled and maximum displacement distance from the previous nesting site providing a representation of movement during the inter-nesting period.

ArcGIS 10 (Environmental Systems Research Institute; Redlands, CA, USA) was used to plot turtle movements from the filtered Argos and Fastloc GPS location datasets. Patterns of inter-nesting movement were determined based on the maximum displacement distance of the turtle between nesting sites and the general direction the turtle moved away from the nesting beach.

\section{Home range}

Home range was estimated by the fixed kernel density method (Worton 1989) for each turtle tracked using Fastloc GPS. The filtered location data (Fastloc only) was used to calculate a median position for each $6 \mathrm{~h}$ period of tracking. This period was selected to ensure the sample size was large enough for kernel analysis (i.e. $n>30$ locations; Seaman et al. 1999). Turtles tracked using Argos transmitters were not considered for home range analysis due to the lower quantity of suitable locations received. We used Geospatial Modelling Environment, an extension to ArcGIS, to calculate fixed kernel density estimates (KDE) using the kde function (Beyer 2012, R Development Core Team 2013). The KDE for each turtle was calculated with least square cross validation as a band width to calculate the smoothing parameter. This approach has been used to delineate home ranges for several other species of marine turtles (see Seminoff et al. 2002, Schofield et al. 2010). A 50\% utilisation distribution (UD) was used to establish the core area of use (Worton 1989, Hart \& Fujisaki 2010).

\section{Potential interaction with the resources industry}

GIS shapefiles of proposed and operational major resource developments in the Pilbara region were 
provided by the Western Australian Department of Mines and Petroleum (DMP). A proposed development is considered major if it has a capital expenditure $>$ \$A20 million, and an operational development is considered major if it has an actual value or anticipated value of production > \$A10 million. Major resource developments not involving offshore construction or dredging were removed from the dataset; these were all terrestrial based with no likely direct impact on coastal and marine ecosystems. We considered interactions to potentially occur between a tracked turtle during its inter-nesting period and a major resource development if the inter-nesting track extended to $<5 \mathrm{~km}$ from the development.

In Western Australia, offshore petroleum exploration and development is regulated by a title system. Petroleum activities can only occur if a company holds a valid title, which in itself provides holders with an exclusive right to apply for further approvals to conduct safe petroleum operations in the area. The title areas provide boundaries within which petroleumrelated activities currently occur or can potentially occur in the future.

The type and location of currently active offshore titles released for petroleum industry activities were provided by the DMP. Title areas are divided into graticular sections. Each section is 5 minutes of latitude by 5 minutes of longitude, with sections to the north of Western Australia having an area of $\sim 84 \mathrm{~km}^{2}$. Five relevant title types exist: exploration permits (for the purpose of seismic surveys and oil/gas well drilling), retention leases (a $5 \mathrm{yr}$ exploration lease), production licence (for the purpose of extracting or producing oil/gas from the ground), infrastructure licence (for the construction of offshore facilities for the storage and processing of oil/gas) and a pipeline licence (for subsea pipelines).

We used 2 metrics to determine which rookeries have inter-nesting turtles that are potentially exposed to current or future offshore activities associated with the petroleum resource industry within the title areas: (1) the proportion of daily median positions for inter-nesting turtles that occurred within the relevant offshore title areas; and (2) the proportion of the core $50 \%$ UD home range area for each inter-nesting turtle that overlapped offshore title areas. These metrics aim to provide a broad indication of the extent of spatial overlap between areas released for petroleum activities and inter-nesting habitat for each rookery and are not to be considered as a direct indication of impact.

\section{Statistical analysis}

All data were tested for distribution normality. A generalised linear mixed effects modelling approach was used to test for differences between individual turtles tracked from different rookeries for distance travelled when inter-nesting, and maximum displacement distance when inter-nesting. The modelling approach used individual turtles as a random effect to account for pseudoreplication, and was fitted in R (R Development Core Team 2013) using the Ime4 contributed package (Bates et al. 2008). Data used in the linear mixed models were tested for distribution normality and checked for homogeneity of variance. p-values were based on likelihood ratio tests conducted using the lmerTest package for $\mathrm{R}$ (Kuznetsova et al. 2014). A non-parametric MannWhitney test was used to test for differences between home range areas for turtles tracked from offshore island rookeries (i.e. Barrow and Thevenard) and mainland rookeries (i.e. Munda and Cemetery).

The relationships between home range size and body size, and home range size and total distance travelled, for each individual turtle, were tested using a Spearman's correlation test.

\section{RESULTS}

A total of 112 individual inter-nesting periods (Thevenard $\mathrm{n}=12$; Barrow $\mathrm{n}=70$; Munda $\mathrm{n}=3$; Cemetery $\mathrm{n}=27$ ) were determined for 56 flatback turtles (Thevenard $\mathrm{n}=6$; Barrow $\mathrm{n}=33$; Munda $\mathrm{n}=2$; Cemetery $n=15$ ). Twenty-five inter-nesting periods were recorded using Argos tags and 87 using Fastloc GPS tags. Each tracked turtle recorded $2.0 \pm 0.9$ (SD) inter-nesting periods (range $=1-4, \mathrm{n}=56$ ) prior to the commencement of its post-nesting migration. Individual inter-nesting periods were determined by direct observation on the beach $(\mathrm{n}=16)$, by haulout data $(\mathrm{n}=52)$ and from recorded positions $(\mathrm{n}=44)$. All inter-nesting periods determined by direct observation on the beach were validated by the process of determining inter-nesting periods from recorded positions. Mean inter-nesting period duration was 13 $\pm 2 \mathrm{~d}$ (range $=8-20, \mathrm{n}=112$ ) .

Argos tags recorded a mean of $30.0 \pm 18.7$ positions per inter-nesting period (range $=6-75, \mathrm{n}=25$ ) at a mean of $3.0 \pm 1.6$ positions per day $(0.7-6.3, \mathrm{n}=25)$ and Fastloc GPS tags recorded a mean of $115.0 \pm 48.4$ positions per inter-nesting period (range $=15-217$, $\mathrm{n}=87$ ) at a mean of $9.0 \pm 3.6$ positions per day $(1.1-17.1, \mathrm{n}=87)$. 


\section{Thevenard Island}

The 6 flatback turtles tracked from Thevenard provided 12 inter-nesting tracks. The turtles travelled a mean total distance of $78.4 \pm 31.6 \mathrm{~km}$ (range $=$ 15.6-126.1, $\mathrm{n}=12$ ) and had a mean maximum displacement distance away from the nesting beach of $25.7 \pm 11.9 \mathrm{~km}$ (range $=6.2-42.5, \mathrm{n}=12$ ) during the inter-nesting period. The mean duration of the internesting period was $11.8 \pm 1.8 \mathrm{~d}$ (range $=8-16, \mathrm{n}=12$ ). Turtles showed a high level of nest site fidelity, returning to the same beach where the transmitter was applied for their subsequent clutch.

Four patterns of inter-nesting movement were identified (Fig. 2a-d); 3 inter-nesting periods ( $\mathrm{N}=3$ turtles) were spent entirely within $10 \mathrm{~km}$ of the prior nesting site, with all tracks circling the island (Fig. 2a). One turtle spent an inter-nesting period moving in an anti-clockwise loop to the north of the island reaching a maximum displacement of $24.4 \mathrm{~km}$ from its prior nesting site (Fig. 2b); 5 inter-nesting periods ( $\mathrm{N}=5$ turtles) were spent moving south towards the mainland and then swimming in a westerly direction, reaching a maximum displacement distance of $42.5 \mathrm{~km}$ (Fig. 2c); and 3 inter-nesting periods ( $\mathrm{N}=3$ turtles) were spent moving south towards the mainland before migrating in an easterly direction, reaching a maximum displacement of $32.0 \mathrm{~km}$ from the prior nesting site (Fig. 2d).

\section{Barrow Island}

The 33 flatback turtles tracked from Barrow provided 70 inter-nesting period tracks. Turtles travelled a mean total distance of $68.7 \pm 48.5 \mathrm{~km}$ (range $=$ $12.5-221.8, \mathrm{n}=70$ ) and had a mean maximum displacement distance away from the nesting beach of $27.2 \pm 20.9 \mathrm{~km}$ (range $=4.0-62.1, \mathrm{n}=70)$. There was no statistically significant difference in distance travelled and displacement distance compared to turtles tracked from Thevenard ( $\mathrm{df}=1, \mathrm{p}>0.05$ ). The mean duration of the inter-nesting period was $13.7 \pm 1.8 \mathrm{~d}$ (range $=10-20, \mathrm{n}=70$ ). The turtles always returned to Barrow to nest but once on the island showed a low level of nest site fidelity to a specific beach, with 21 of the 33 turtles returning to nest on a different beach to the one where the transmitter was applied.

Four patterns of inter-nesting movement from the Barrow flatback turtles were identified (Fig. 3a-d); 26 inter-nesting periods ( $\mathrm{N}=13$ turtles) were spent within $10 \mathrm{~km}$ of the prior nesting site to the east of Barrow, with turtles spending time within a deep water channel formed between 2 nearshore reefs

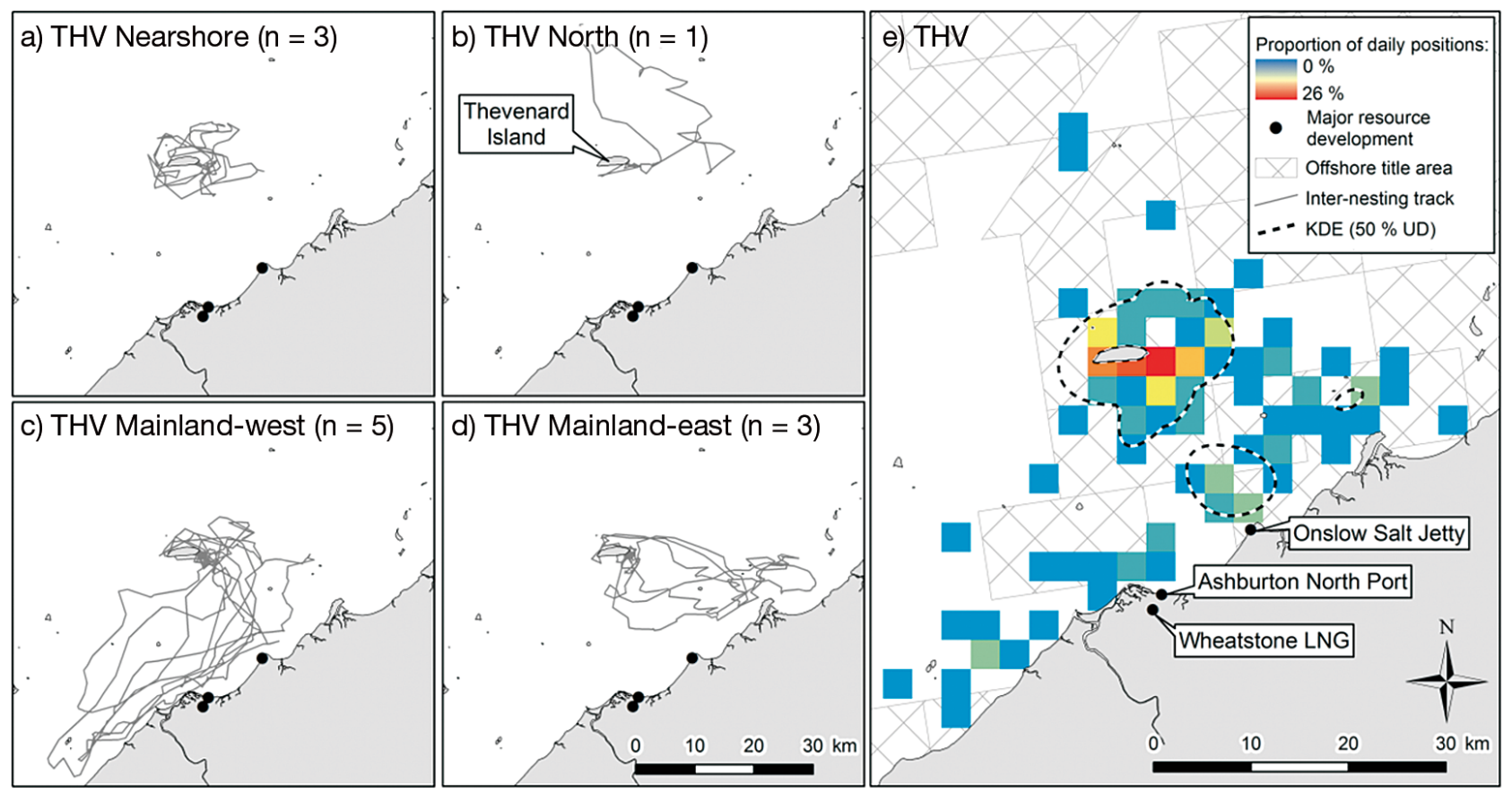

Fig. 2. (a-d) Thevenard Island (THV; Western Australia) inter-nesting track distribution and potential interaction with major resource projects. (e) Density distribution of all median daily positions ( $3 \mathrm{~km}^{2}$ grid) and merged boundaries of core home range areas (KDE [50\% UD]) (KDE: kernel density estimate; UD: utilisation distribution) for all turtles tracked from Thevenard Island in relation to offshore title areas 


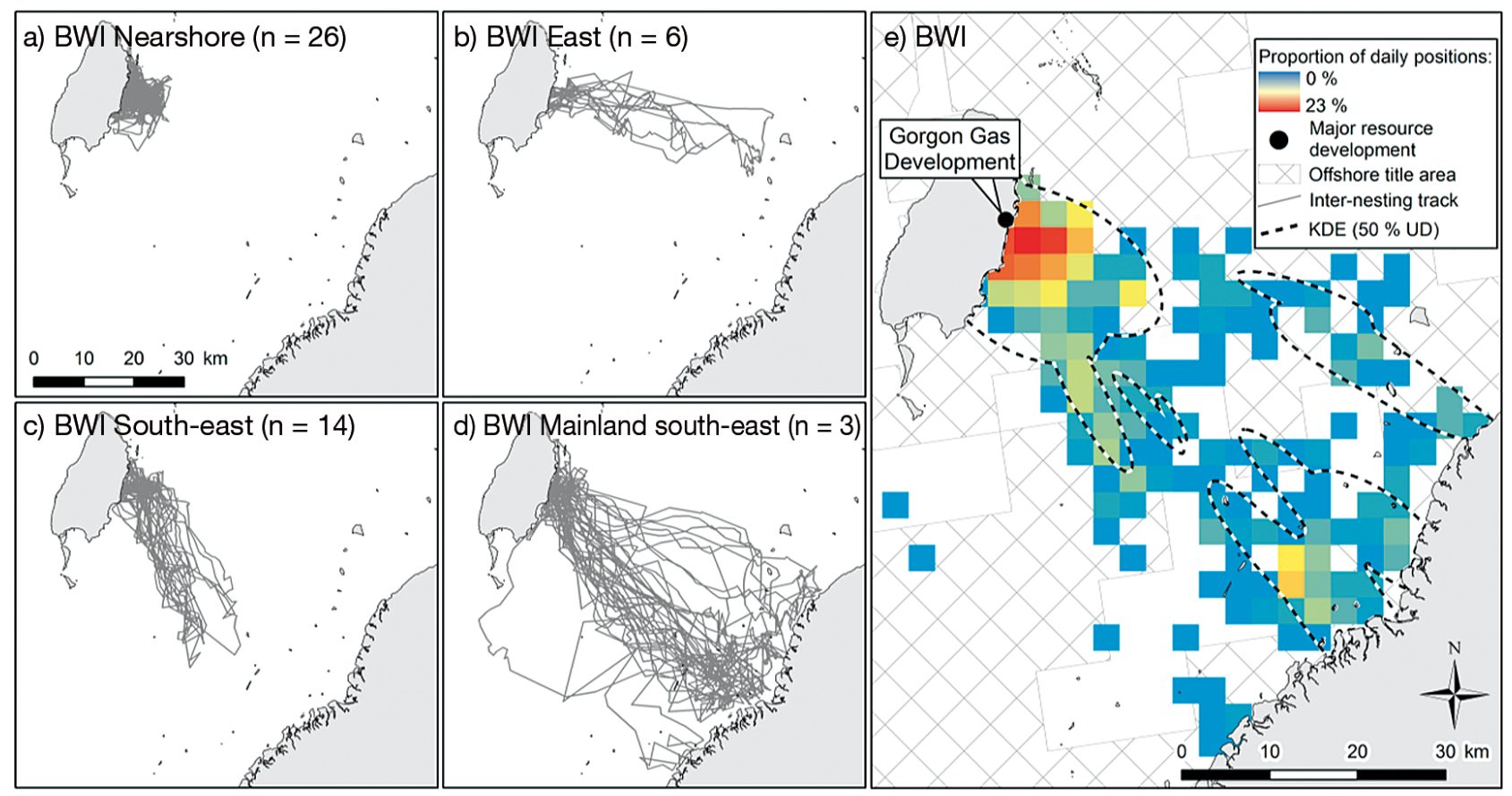

Fig. 3. (a-d) Barrow Island (BWI; Western Australia) inter-nesting track distribution and potential interaction with major resource projects. (e) Density distribution of all median daily positions ( $3 \mathrm{~km}^{2}$ grid) and merged boundaries of core home range areas (KDE [50\% UD]) for all turtles tracked from Barrow Island in relation to offshore title areas

(Fig. 3a); 6 inter-nesting periods ( $\mathrm{N}=4$ turtles) were spent moving in an easterly direction $>10 \mathrm{~km}$ away from Barrow, with none of the tracks extending to within $10 \mathrm{~km}$ of the mainland (Fig. 3b); 14 internesting periods ( $\mathrm{N}=9$ turtles) were spent moving $>10 \mathrm{~km}$ away from Barrow in a south-east direction, with none of the tracks extending to within $10 \mathrm{~km}$ of the mainland (Fig. 3c); and 12 inter-nesting periods ( $\mathrm{N}=9$ turtles) were spent moving away from Barrow in a south-east direction, spending part of their internesting period within $10 \mathrm{~km}$ of the mainland coast (Fig. 3d).

\section{Mundabullangana}

The 2 tracked flatback turtles provided 3 internesting period tracks. Turtles travelled a mean total distance of $38.7 \pm 8.6 \mathrm{~km}$ (range $=31.9-48.4, \mathrm{n}=3$ ) and had a mean maximum displacement distance away from the nesting beach of $11.7 \pm 4.0 \mathrm{~km}$ (range $=8.5-16.2, \mathrm{n}=3$ ). The distance travelled was statistically similar to turtles tracked from Thevenard $(\mathrm{df}=1$, $\mathrm{p}>0.05$ ) and Barrow ( $\mathrm{df}=1, \mathrm{p}>0.05$ ). The mean duration of the inter-nesting period was $11.0 \pm 1.0 \mathrm{~d}$ (range $=10-12, \mathrm{n}=3$ ). Turtles showed a high level of nest site fidelity, returning to the same beach where the transmitter was applied for subsequent clutches.
Two patterns of inter-nesting movement were identified (Fig. 4a,b); 1 turtle spent 2 inter-nesting periods within $10 \mathrm{~km}$ of the prior nesting site adjacent to the nesting beach (Fig. 4a), and 1 turtle spent an internesting period moving to the west of the nesting beach, extending up to a maximum displacement of $16.2 \mathrm{~km}$ away from the previous nesting site (Fig. 4b).

\section{Cemetery Beach}

The 15 flatback turtles were tracked for 27 internesting periods. Turtles travelled a mean total distance of $57.6 \pm 37.2 \mathrm{~km}$ (range $=14.4-145.8, \mathrm{n}=27$ ) during each inter-nesting period and had a mean maximum displacement distance of $22.9 \pm 16.4 \mathrm{~km}$ (range $=3.4-56.6, \mathrm{n}=27$ ). The distance travelled was similar to turtles tracked from Thevenard $(\mathrm{df}=1$, $p>0.05)$, Barrow $(d f=1, p>0.05)$ and Munda $(d f=1$, $p>0.05$ ). The mean duration of the inter-nesting period was $12.0 \pm 1.9 \mathrm{~d}$ (range $=10-18, \mathrm{n}=27$ ). With one exception the turtles showed a high level of nest site fidelity, always returning to Cemetery to nest. The exception was a turtle which moved approximately $60 \mathrm{~km}$ away from Cemetery to nest at Munda.

Four patterns of inter-nesting movement were identified (Fig. 5a-d); 8 inter-nesting periods ( $N=6$ turtles) were spent within $10 \mathrm{~km}$ of the prior nesting 

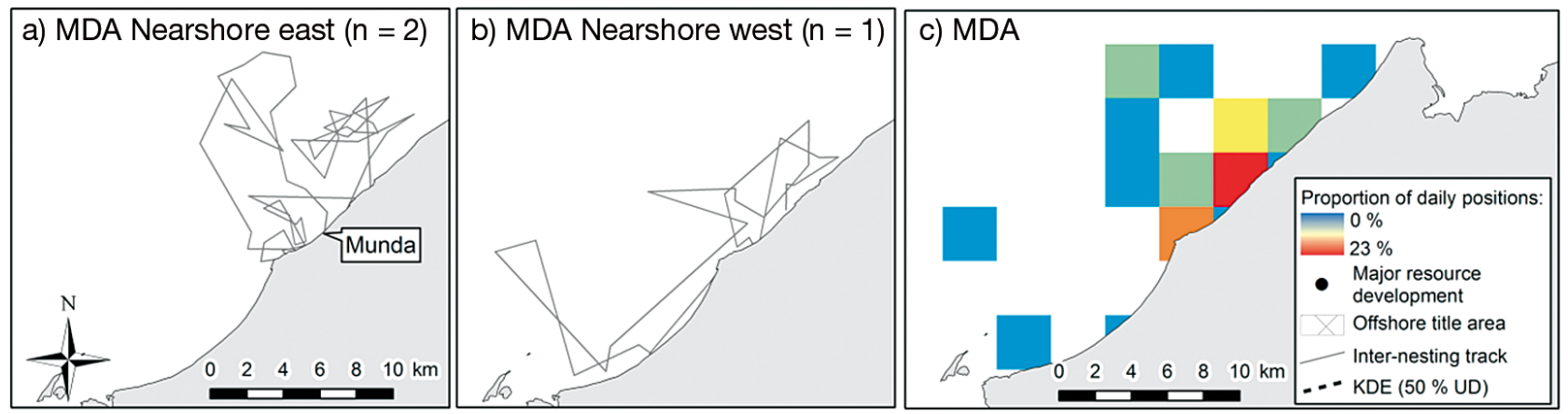

Fig. 4. $(\mathrm{a}, \mathrm{b})$ Mundabullangana (MDA; Western Australia) inter-nesting track distribution and potential interaction with major resource projects. (c) Density distribution of all median daily positions ( $3 \mathrm{~km}^{2} \mathrm{grid}$ ) in relation to offshore title areas

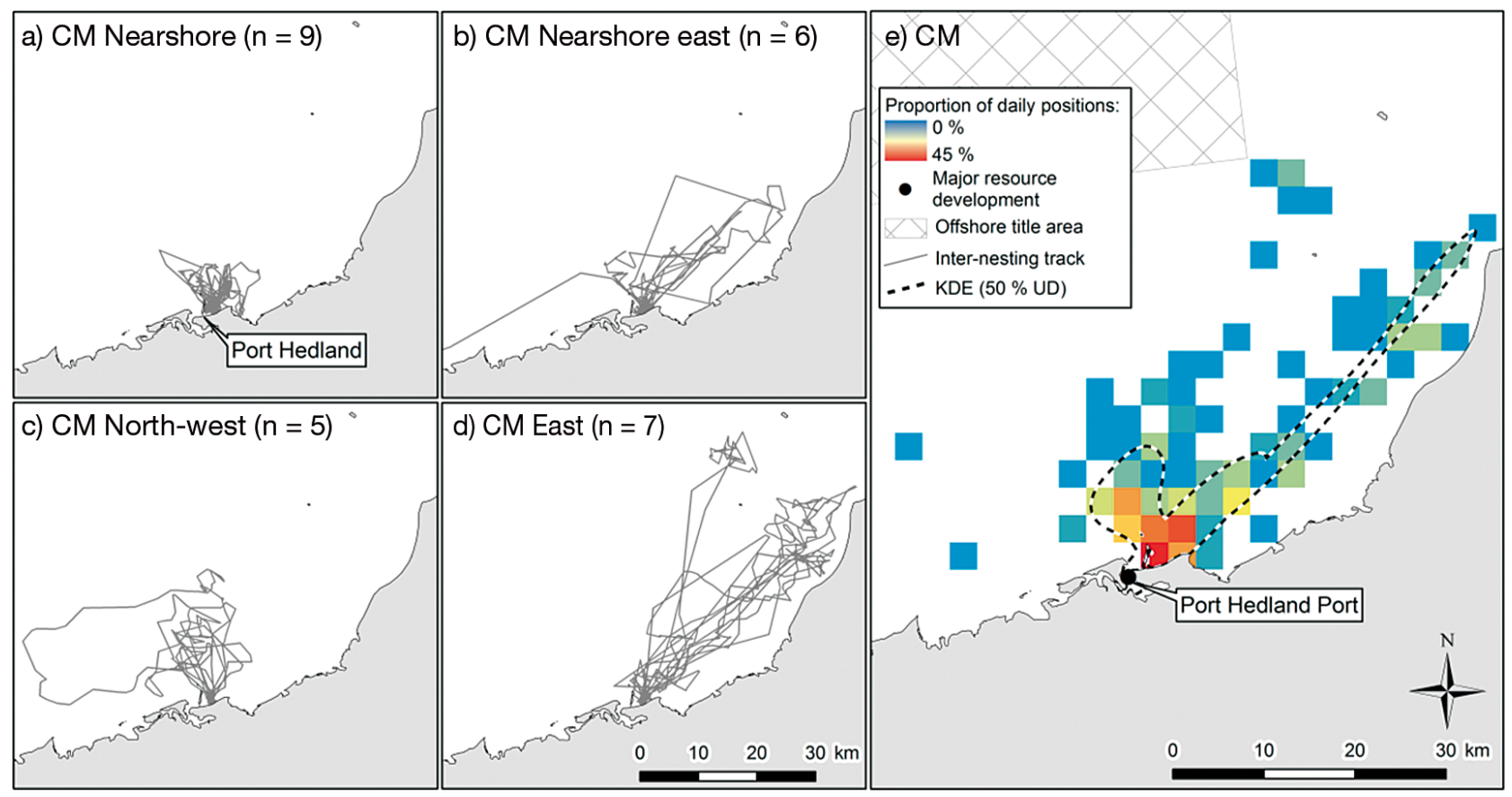

Fig. 5. (a-d) Cemetery beach (CM), Port Hedland, Western Australia, inter-nesting track distribution and potential interaction with major resource projects. (e) Density distribution of all median daily positions ( $3 \mathrm{~km}^{2}$ grid) and merged boundaries of core home range areas (KDE [50\% UD]) for all turtles tracked from CM in relation to offshore title areas

site in a nearshore area north of Cemetery (Fig. 5a); 6 inter-nesting periods ( $\mathrm{N}=6$ turtles) migrated to an area $>10 \mathrm{~km}$ but $<30 \mathrm{~km}$ to the east of Cemetery (Fig. 5b); 6 inter-nesting periods $(\mathrm{N}=4$ turtles) migrated $>10 \mathrm{~km}$ from Cemetery in a north-westerly direction (Fig. 5c); and 7 inter-nesting periods ( $N=6$ turtles) migrated in an easterly direction to an area $>30 \mathrm{~km}$ from Cemetery (Fig. 5d).

\section{Home range}

The size of inter-nesting core-use areas (50\% UD) for each tracked turtle ranged from $1.4-601.1 \mathrm{~km}^{2}$ at Barrow (mean $143.1 \pm 170.9 \mathrm{~km}^{2}, \mathrm{n}=26$ ), $4.6-$ $166.9 \mathrm{~km}^{2}$ at Cemetery (mean $75.7 \pm 61.7 \mathrm{~km}^{2}, \mathrm{n}=9$ ) and $89.0-337.1 \mathrm{~km}^{2}$ at Thevenard (mean $191.6 \pm$ $91.3 \mathrm{~km}^{2}, \mathrm{n}=6$ ). Body size did not correlate with size of core-use areas ( $\mathrm{n}=41$, Spearman's rank correlation coefficent $\left[r_{S}\right]=0.022, p=0.892$ ). There was no significant difference in home range area for turtles tracked from offshore islands (Barrow and Thevenard), compared to turtles tracked from the mainland (Cemetery) (Mann-Whitney $U=177, \mathrm{p}>0.05$ ). There was a significant positive correlation between the total distance travelled during the inter-nesting period for each individual turtle and the size of their home range area $\left(\mathrm{n}=41, \mathrm{r}_{\mathrm{S}}=0.751, \mathrm{p}<0.0001\right)$. 


\section{Potential interaction with the resources industry}

No flatback turtles tracked from Munda and Cemetery Beach recorded median daily positions within an offshore petroleum title area. In contrast, median daily positions of turtles from Thevenard Island and Barrow Island showed a high degree of overlap with offshore petroleum title areas during their overall inter-nesting period, $80.8 \pm 8.0 \%$ (range $=68.4-92.9, \mathrm{n}=6$ ) and $87.3 \pm 17.8 \%$ (range $=40.6-$ 100.0, $\mathrm{n}=33$ ), respectively (Figs. 2e \& 3e).

There was no overlap between inter-nesting core home range areas (50\% UD KDE) of individual turtles tracked from Cemetery and offshore petroleum title areas (Fig. 5e). The overlap of core home range areas with offshore petroleum title areas for individual turtles tracked from Thevenard and Barrow Island was $85.7 \pm 5.3 \%$ (range $=75.2-89.9, \mathrm{n}=6)$ and $88.6 \pm 19.9 \%$ (range $=27.6-100, \mathrm{n}=26)$, respectively (Table 1, Figs. 2e \& 3e).

Twelve major resource developments involving offshore infrastructure or dredging were identified between Exmouth and Port Hedland; 7 developments are currently operating, 3 are under construction and 2 are proposed. At Thevenard, 4 of 12 (33\%) inter-nesting tracks passed within $5 \mathrm{~km}$ of 3 major resource developments located on the mainland: Wheatstone liquefied natural gas (LNG) plant (under development), Ashburton North Multi-user Port and Handling Facility (proposed), and the Onslow Salt Jetty (operating), situated 26, 21, and $25 \mathrm{~km}$ to the south of Thevenard, respectively. All 4 tracks followed the same mainland-west distribution pattern (Fig. 2c). All inter-nesting tracks from Barrow were situated within $5 \mathrm{~km}$ of the Gorgon Gas Development (under development), with 26 inter-nesting tracks remaining $<10 \mathrm{~km}$ from Barrow (Fig. 3a). No individual inter-nesting tracks from Munda were located within $5 \mathrm{~km}$ of an existing or planned major resource development. All inter-nesting tracks from Cemetery were situated within $5 \mathrm{~km}$ of the port expansion at Port Hedland (planned), with 8 inter-nesting tracks remaining $<10 \mathrm{~km}$ from Cemetery (Fig. 5a).

\section{DISCUSSION}

Flatback turtles from 4 rookeries within the same genetic management unit demonstrated variable patterns of inter-nesting movement. At each rookery some flatback turtles remained $<10 \mathrm{~km}$ from the nesting beach; some turtles from offshore island rookeries moved up to $62.1 \mathrm{~km}$ towards the Australian mainland coast; and some turtles from 1 mainland rookery moved adjacent to the coast, up to $56.6 \mathrm{~km}$ away from the nesting beach. With the exception of Mundabullangana, some turtles from each rookery were recorded in marine areas that overlap with existing and potential industry development.

Marine turtles are believed to be capital breeders (Hamann et al. 2002) and thus need to conserve energy during the nesting season. Hence, the main driver behind the inter-nesting behaviour is hypothesised to be related to optimisation of energy reserves in a manner most suited to the localised conditions to ensure maximum seasonal reproductive output (Houghton et al. 2002). It is therefore likely that, similar to other species, biophysical conditions play a role in driving the variation that we found in internesting patterns among rookeries (Hays et al. 2002, Sperling 2007, Schofield et al. 2010, Shillinger et al. 2010).

One environmental variable known to directly influence the length of the inter-nesting interval is sea surface temperature, with warmer sea surface temperatures in the inter-nesting habitat resulting in shorter intervals (Sato et al. 1998, Hays et al. 2002, Fossette et al. 2012). As such, exposure of females to warmer sea surface temperatures across a nesting season may reduce the overall length of time required to lay the full complement of clutches (Hays et al. 2002). Our data demonstrate considerable variation in inter-nesting space use, both among and within females. This variation could be related to spatio-temporal variation of sea surface temperature and behavioural thermoregulation, with inter-nesting flatbacks seeking higher ambient water temperatures to maintain a higher body temperature, as has been demonstrated in other marine turtle species (Schofield et al. 2009, Fossette et al. 2012).

Other authors have demonstrated that one behavioural strategy employed by inter-nesting marine turtles to optimise energy reserves, is to rest and remain inactive on the seabed (Hays et al. 2000, Fossette et al. 2012). In particular it is suggested that, when resting, turtles (1) use deeper and slower moving water in order to remain on the seabed for longer periods, thus minimising the energy cost of commuting to the surface (Hays et al. 2000, Houghton et al. 2002, Minamikawa et al. 2000) and (2) alter their dive behaviour to utilise a specific bathymetric depth that maximises the oxygen store, while still attaining near-neutral buoyancy on the seabed (Hays et al. 2000). It is therefore possible that the inter-nesting patterns we found are related to bathymetry and could reflect a search by the females for areas of suit- 
able depth or hydrodynamic conditions in which efficient resting can take place. Our data highlight an important research gap that could be addressed by combining inter-nesting habitat boundaries and travel paths overlaid with bathymetry and sea surface temperature.

The long circuitous movement patterns required to locate a suitable inter-nesting area may place pressure on turtles' limited energy budget (Houghton et al. 2002). It is possible that the individual turtles that demonstrated longer than average movement patterns in this study were searching for inter-nesting habitat of suitable hydrodynamic conditions. The long search times could result if no suitable habitats are encountered immediately following departure from the nesting beach. Further investigation of localised hydrodynamic conditions in relation to specific movement, orientation and dive patterns, in tandem with development of a habitat suitability model, is required to either confirm or refute this hypothesis and elucidate factors affecting inter-nesting habitat selection. Doing so would make an important contribution to our understanding of turtle reproductive ecology (Hamann et al. 2010).

The flatback turtle is listed as a threatened species under Australian legislation, making the species a 'Matter of National Environmental Significance (MNES)' under the Environment Protection and Biodiversity Conservation (EPBC) Act. Therefore, understanding the interactions between major resource developments, petroleum title areas and the regional distribution of inter-nesting habitat selected by flatback turtles is critical in predicting the cumulative risk and exposure to anthropogenic disturbance, and in establishing long-term population viability. Our results indicate that flatback turtles nesting at Thevenard and Barrow Islands use inter-nesting areas that overlap with title areas released for petroleumrelated activities, and Thevenard turtles were exposed to 3 planned or operating major resource developments situated away from their nesting site. Because the flatback turtle is listed as an MNES, our results are important for 3 reasons: (1) the presence of flatback turtles within a proposed development footprint will trigger the need for an EIA and ensure the referral of the project to the Australian Government's Department of Environment for approval; (2) existing environmental legislation does not account for potential cumulative impact (Grech et al. 2013); and (3) the EIA scoping process for a planned major resource development may not consider the potential offshore presence of inter-nesting flatback turtles from rookeries situated further away, with our results suggest- ing turtles from rookeries situated up to $62.1 \mathrm{~km}$ away would need to be considered (based on the maximum inter-nesting displacement distance recorded in this study). In addition, turtles that remained in the nearshore environment at Barrow and Cemetery were potentially exposed to industryrelated vessel movements associated with major resource developments situated near their respective rookeries, as well as vessel movements linked to the existing port at Port Hedland. Our findings have important implications for both the Australian Government and industry when quantifying project-specific and cumulative risk and when assessing the conservation management of flatback turtle nesting and inter-nesting habitat in Western Australia.

Marine Protected Areas (MPAs) are recognised as a viable and proven conservation measure for species protection during biologically sensitive periods, and in ecologically sensitive areas of their known geographic and temporal ranges (Roberts 2005, Scott et al. 2012). Questions remain regarding the relative effectiveness of MPAs in providing adequate protection for species that are highly mobile, distributed across a wide geographic range and exhibit unpredictable movement patterns (Roberts et al. 2003, Dobbs et al. 2007, Dryden et al. 2008), features that were demonstrated by flatback turtles within this study. However, we also found some inter-nesting features that were consistent across rookeries. In particular, at all 4 rookeries we identified a nearshore $(<10 \mathrm{~km})$ inter-nesting distribution pattern from some of the tracked turtles along with their core inter-nesting home range areas. This consistency highlights an opportunity to implement boundary-specific protection measures, effectively encompassing a large proportion of the inter-nesting population and/or habitat (as defined by boundaries of the core home range areas) and possibly incorporating them into industryspecific management or operational plans.

Australian Federal and State legislation requires protection measures designed to manage, mitigate or remove the predicted species-specific risks of each project or development. Localised protection measures are devised based on the findings of EIAs and implemented through project-specific Environmental Management Plans. Lack of data regarding offshore marine turtle abundance and distribution therefore constrains development of effective management measures for this species, or the species may be entirely overlooked during the EIA phase. Our data, which demonstrate that turtles can be exposed to risks from multiple projects, would suggest that existing legislation may not consider cumulative risks to 
the same individuals and rookeries across multiple projects. Variability in inter-nesting distribution outlined in this study should therefore be considered when determining management measures.

Overall, the wide ranging inter-nesting movement patterns shown in this study highlight a need for the Australian Government and industry to expand the scope of EIA, ensuring adequate protection is provided to inter-nesting flatback turtles that can travel up to $62.1 \mathrm{~km}$ away from their rookery between nesting events. In addition, the similar nearshore internesting movement pattern recorded by some flatback turtles at each rookery offers an opportunity to establish boundaries for small-scale spatial and temporal protection measures that could provide protection for a large proportion of the inter-nesting population.

Acknowledgements. We thank staff and volunteers at Pendoley Environmental for field support, notably P. Tod, R. Murliss, N. Sillem, K. Ball, L. Claessen, T. Sunderland and N. Fitzsimmons. Chevron Australia (D. Moro and R. Lagdon), BHP Billiton (S. Mavrick) and URS provided funding and logistical support for this project. We thank P. Tod of Crackpots Ltd for supplying harnesses and attachment advice. We thank C. Bell, S. Maxwell and 2 anonymous reviewers for their comments on this manuscript. Satellite attachment was conducted under the Department of Parks and Wildlife licence numbers: SF005670, SF006705, SF006706, SF007088, SF007143, SF007144, SF007641 and SF007643. M.H. is funded by the Australian Government's National Environmental Research Program. This manuscript forms part of P.A.W.'s PhD research at James Cook University.

\section{LITERATURE CITED}

Bailey H, Senior B, Simmons D, Rusin J, Picken G, Thompson PM (2010) Assessing underwater noise levels during pile-driving at an offshore windfarm and its potential effects on marine mammals.Mar Pollut Bull 60(6): 888-897

Bates D, Maechler M, Dai B (2008). lme4: linear mixedeffects models using S4 classes. http://lme4.r-forge.rproject.org

Beyer HL (2012) Geospatial Modelling Environment (Version 0.6.0.0). www.spatialecology.com/gme

Blumenthal JM, Solomon JL, Bell CD, Austin TJ and others (2006) Satellite tracking highlights the need for international cooperation in marine turtle management. Endang Species Res 2:51-61

> Carstensen J, Henriksen OD, Teilmann J (2006) Impacts of offshore wind farm construction on harbour porpoises: acoustic monitoring of echolocation activity using porpoise detectors (T-PODS). Mar Ecol Prog Ser 321: 295-308

CLS (2011) Argos user's manual. Available from www.argossystem.org/files/pmedia/public/r363_9_argos_users_ manual-v1.6.3.pdf (accessed 10 June 2014)

> Coyne MS, Godley BJ (2005) Satellite Tracking and Analysis Tool (STAT): an integrated system for archiving, analyz- ing and mapping animal tracking data. Mar Ecol Prog Ser 301:1-7

Craig P, Parker D, Brainard R, Rice M, Balazs G (2004) Migrations of green turtles in the central South Pacific. Biol Conserv 116:433-438

Dickerson DD, Richardson JI, Ferris JS, Bass AL, Wolff M (1991) Entrainment of sea turtles by hopper dredges in Cape Canaveral and Kings Bay ship channels. Environmental effects of dredging, Vol D-91-1. US Army Engineer Waterways Experiment Station, Vicksburg, MS

Dobbs K, Fernandes L, Slegers S, Jago B and others (2007) Incorporating marine turtle habitats into the marine protected area design for the Great Barrier Reef Marine Park, Queensland, Australia. Pac Conserv Biol 13:293-302

> Dryden J, Grech A, Moloney J, Hamann M (2008) Rezoning of the Great Barrier Reef World Heritage Area: Does it afford greater protection for marine turtles? Wildl Res 35: 477-485

Dutton P, Broderick D, FitzSimmons N (2002) Defining management units: molecular genetics. In: Kinan J (eds) Proc Western Pacific Sea Turtle Cooperative Research \& Management Workshop. Western Pacific Regional Fishery Management Council, Honolulu, HI, p 93-101

Eckert SA (2006) High-use oceanic areas for Atlantic leatherback sea turtles (Dermochelys coriacea) as identified using satellite telemetered location and dive information. Mar Biol 149:1257-1267

> Fossette S, Schofield G, Lilley MKS, Gleiss A, Hays GC (2012) Acceleration data reveals the energy management strategy of a marine ectotherm during reproduction. Funct Ecol 26:324-333

Fuller WJ, Broderick AC, Phillips RA, Silk JRD, Godley BJ (2008) Utility of geolocating light loggers to indicate atsea movements in sea turtles. Endang Species Res 4: $139-146$

Gill AB (2005) Offshore renewable energy: ecological implications of generating electricity in the coastal zone. J Appl Ecol 42:605-615

Godley BJ, Broderick AC, Glen F, Hays GC (2003) Post-nesting movements and submergence patterns of loggerhead marine turtles in the Mediterranean assessed by satellite tracking. J Exp Mar Biol Ecol 287:119-134

Godley BJ, Blumenthal JM, Broderick AC, Coyne MS, Godfrey MH, Hawkes LA, Witt MJ (2008) Satellite tracking of sea turtles: Where have we been and where do we go next? Endang Species Res 4:3-22

Grech A, Bos M, Brodie J, Coles R and others (2013) Guiding principles for the improved governance of port and shipping impacts in the Great Barrier Reef. Mar Pollut Bull 75:8-20

> Halpern BS, Walbridge S, Selkoe KA, Kappel CV and others (2008) A global map of human impact on marine ecosystems. Science 319:948-952

Hamann M, Jessop TS, Limpus CJ, Whittier JM (2002) Interactions among endocrinology, seasonal reproductive cycles and the nesting biology of the female green sea turtle. Mar Biol 140:823-830

Hamann M, Limpus CJ, Owens DW (2003) Reproductive cycles of males and females. In: Lutz PL, Musick JA, Wyneken J (eds) The biology of sea turtles, Vol 2. CRC Press, Boca Raton, FL, p 135-161

Hamann M, Godfrey MH, Seminoff JA, Arthur K and others (2010) Global research priorities for sea turtles: informing management and conservation in the 21 st century. Endang Species Res 11:245-269 
Hamel MA, McMahon CR, Bradshaw CJA (2008) Flexible inter-nesting behaviour of generalist olive ridley turtles in Australia. J Exp Mar Biol Ecol 359:47-54

Harewood A, Horrocks J (2008) Impacts of coastal development on hawksbill hatchling survival and swimming success during the initial offshore migration. Biol Conserv 141:394-401

> Hart KM, Fujisaki I (2010) Satellite tracking reveals habitat use by juvenile green sea turtles Chelonia mydas in the Everglades, Florida, USA. Endang Species Res 11: 221-232

> Hawkes LA, Broderick AC, Coyne MS, Godfrey MH, Godley BJ (2007) Only some like it hot? Quantifying the environmental niche of the loggerhead sea turtle. Divers Distrib 13:447-457

Hays GC (2008) Sea turtles: a review of some key recent discoveries and remaining questions. J Exp Mar Biol Ecol $356: 1-7$

Hays GC, Luschi P, Papi F, del Seppia C, Marsh R (1999) Changes in behaviour during the inter-nesting period and post-nesting migration for Ascension Island green turtles. Mar Ecol Prog Ser 189:263-273

> Hays GC, Adams CR, Broderick AC, Godley BJ, Lucas DJ, Metcalfe JD, Prior AA (2000) The diving behaviour of green turtles at Ascension island. Anim Behav 59: $577-586$

> Hays GC, Akeson S, Godley BJ, Luschi P, Santidrian P (2001) The implications of location accuracy for the interpretation of satellite-tracking data. Anim Behav 61: 1035-1040

> Hays GC, Broderick AC, Glen F, Godley BJ, Houghton JDR, Metcalfe JD (2002) Water temperature and inter-nesting intervals for loggerhead (Caretta caretta) and green (Chelonia mydas) sea turtles. J Therm Biol 27:429-432

Hays GC, Houghton JDR, Isaacs C, King RS, Lloyd C, Lovell P (2004) First records of oceanic dive profiles for leatherback turtles, Dermochelys coriacea, indicate behavioural plasticity associated with long-distance migration. Anim Behav 67:733-743

Hazel J (2009) Evaluation of fast-acquisition GPS in stationary tests and fine-scale tracking of green turtles. J Exp Mar Biol Ecol 374:58-68

Houghton JDR, Broderick AC, Godley BJ, Metcalfe JD, Hays GC (2002) Diving behaviour during the internesting interval for loggerhead turtles Caretta caretta nesting in Cyprus. Mar Ecol Prog Ser 227:63-70

Human BA, McDonald JI (2009) Knowledge review and gap analysis: resource condition monitoring in the Pilbara and Kimberley regions of Western Australia. Department of Fisheries, Government of Western Australia Coastal and Marine Resource Condition Monitoring - Scoping Project Final NRM Report, Project 073007, Part 1. Fisheries Research Report 197, Department of Fisheries, Perth

Kuznetsova A, Brockhoff PB, Christensen RHB (2014) lmerTest: tests for random and fixed effects for linear mixed effect models (lmer objects of lme4 package). RVersion:1.1-0. http://cran.r-project.org/web/packages/ lmerTest/index.html

Limpus CJ (2007) A biological review of Australian marine turtle species. 5. Flatback turtle, Natator depressus (Garman). Queensland Environmental Protection Agency, Brisbane. www.austurtle.org.au/SeaTurtleBiology/flat back_Garman.pdf

Lutcavage ME, Lutz PL, Bossart GD, Hudson DM (1995) Physiologic and clinicopathologic effects of crude oil on loggerhead sea turtles. Arch Environ Contam Toxicol 28: 417-422

Madsen PT, Wahlberg M, Tougaard J, Lucke K, Tyack P (2006) Wind turbine underwater noise and marine mammals: implications of current knowledge and data needs. Mar Ecol Prog Ser 309:279-295

> Maxwell SM, Breed GA, Nickel BA, Makanga-Bahouna J and others (2011) Using satellite tracking to optimize protection of long-lived marine species: olive ridley sea turtle conservation in Central Africa. PLoS ONE 6: e19905

Maxwell SM, Hazen EL, Bograd SJ, Halpern BS and others (2013) Cumulative human impacts on marine predators. Nat Commun 4 (2688):1-9

Miller JD (1985) Embryology of marine turtles. In: Gans C (ed) Biology of the reptilia, development, Vol 14. J Wiley \& Sons, New York, NY, p 269-328

Miller JD (1997) Reproduction in sea turtles. In: Lutz PL, Musick JA (eds) The biology of sea turtles. CRC Press, Boca Raton, FL, p 51-81

Minamikawa S, Naito Y, Sato K, Matsuzawa Y, Bando T, Sakamoto W (2000) Maintenance of neutral buoyancy by depth selection in the loggerhead turtle Caretta caretta. J Exp Biol 203:2967-2975

$\mathrm{Ng}$ SL, Leung S (2003) Behavioural response of Indo-Pacific humpback dolphin (Sousa chinensis) to vessel traffic. Mar Environ Res 56:555-567

Pendoley K (2005) Sea turtles and industrial activity on the north west shelf, Western Australia. PhD dissertation, Murdoch University, Perth

Pendoley K, Schofield G, Whittock PA, Ierodiaconou D, Hays GC (2014) Multi-species use of a coastal migratory corridor connecting Marine Protected Areas. Mar Biol 161:1455-1466

R Development Core Team (2013) R: a language and environment for statistical computing. R Foundation for Statistical Computing, Vienna

Roberts CM (2005) Marine Protected Areas and biodiversity conservation. Chapter 16. In: Norse EA, Crowder LB (eds) Marine conservation biology - the science of maintaining the sea's biodiversity. Marine Conservation Biology Institute \& Island Press, Washington, DC, p 265-279

Roberts CM, Branch G, Bustamante RH, Castilla JC and others (2003) Application of ecological criteria in selecting marine reserves and developing reserve networks. Ecol Appl 13:S215-S228

Sato K, Matsuzawa Y, Tanaka H, Bando T, Minamikawa S, Sakamoto W, Naito Y (1998) Internesting intervals for loggerhead turtles, Caretta caretta, and green turtles, Chelonia mydas, are affected by temperature. Can J Zool 76:1651-1662

Schofield G, Bishop CM, MacLean G, Brown P and others (2007) Novel GPS tracking of sea turtles as a tool for conservation management. J Exp Mar Biol Ecol 347:58-68

- Schofield G, Bishop CM, Katselidis KA, Dimopoulos P, Pantis JD, Hays GC (2009) Microhabitat selection by sea turtles in a dynamic thermal marine environment. J Anim Ecol 78:14-21

Schofield G, Hobson VJ, Lilley MKS, Katselidis KA, Bishop CM, Brown P, Hays GC (2010) Inter-annual variability in the home range of breeding turtles: implications for current and future conservation management. Biol Conserv 143:722-730

Schofield G, Scott R, Dimadi A, Fossette S and others (2013) Evidence based marine protected area planning for a 
highly mobile endangered marine vertebrate. Biol Conserv 161:101-109

Scott R, Hodgson DJ, Witt MJ, Coyne MS and others (2012) Global analysis of satellite tracking data shows that adult green turtles are significantly aggregated in Marine Protected Areas. Glob Ecol Biogeogr 21:1053-1061

Seaman DE, Millspaugh JJ, Kernohan BJ, Brundige GC, Raedeke KJ, Gitzen RA (1999) Effects of sample size on kernel home range estimates. J Wildl Manag 63:739-748

Seminoff JA, Resendiz A, Nichols WJ (2002) Home range of green turtles Chelonia mydas at a coastal foraging area in the Gulf of California, Mexico. Mar Ecol Prog Ser 242: 253-265

Seney EE, Landry AM Jr (2008) Movements of Kemp's ridley sea turtles nesting on the upper Texas coast: implications for management. Endang Species Res 4:73-84

Shaver DJ, Rubio C (2008) Post-nesting movements of wild and head-started Kemp's ridley sea turtles Lepidochelys kempii in the Gulf of Mexico. Endang Species Res 4: 43-55

Shillinger GL, Swithenbank AM, Bograd SJ, Bailey H and others (2010) Identification of high-use internesting habitats for eastern Pacific leatherback turtles: role of the environment and implications for conservation. Endang Species Res 10:215-232

Shimada T, Jones R, Limpus C, Hamann M (2012) Improving data retention and home range estimates by data-driven screening. Mar Ecol Prog Ser 457:171-180

Sperling JB (2007) The behaviour and physiology of the gravid flatback turtle. PhD dissertation, University of Queensland, Brisbane

Sperling JB, Guinea ML (2004) A harness for attachment of satellite transmitters on flatback turtles. Mar Turtle Newsl 103:11-13

Stewart GB, Pullin AS, Coles CF (2007) Poor evidence-base for assessment of wind farm impacts on birds. Environ Conserv 34:1-11

Editorial responsibility: Paolo Casale,

Rome, Italy
Stoneburner DL (1982) Satellite telemetry of loggerhead sea turtle movement in the Georgia Bight. Copeia 1982: 400-408

Thompson PM, Lusseau D, Barton T, Simmons D, Rusin J, Bailey $H$ (2010) Assessing the responses of coastal cetaceans to the construction of offshore wind turbines. Mar Pollut Bull 60:1200-1208

> Troëng S, Dutton PH, Evans D (2005) Migration of hawksbill turtles Eretmochelys imbricata from Tortuguero, Costa Rica. Ecography 28:394-402

Troëng S, Evans DR, Harrison E, Lagueux CJ (2005a) Migration of green turtles Chelonia mydas from Tortuguero, Costa Rica. Mar Biol 148:435-447

Waayers DA, Smith LM, Malseed BE (2011) Inter-nesting distribution of green turtles (Chelonia mydas) and flatback turtles (Natator depressus) at the Lacepede Islands, Western Australia. J R Soc West Aust 94:359-364

Whiting S, Hartley S, Lalara S, White D, Bara T, Maminyamunja C, Wurramarrba L (2006) Hawksbill turtle tracking as part of initial sea turtle research and conservation at Groote Eylandt, Northern Australia. Mar Turtle Newsl 114:14-15

- Witt MJ, Åkesson S, Broderick AC, Coyne MS and others (2010) Assessing accuracy and utility of satellite-tracking data using Argos-linked Fastloc-GPS. Anim Behav 80: 571-581

Worton B (1989) Kernel methods for estimating the utilisation distribution in home-range studies. Ecology 70 : 164-168

Zbinden JA, Aebischer A, Margaritoulis D, Arlettaz R (2007) Insights into the management of sea turtle internesting area through satellite telemetry. Biol Conserv 137:157-162

> Zbinden JA, Aebischer A, Margaritoulis D, Arlettaz R (2008) Important areas at sea for adult loggerhead sea turtles in the Mediterranean Sea: satellite tracking corroborates findings from potentially biased sources. Mar Biol 153: 899-906

Submitted: July 4, 2013; Accepted: June 16, 2014 Proofs received from author(s): October 2, 2014 